\title{
Reminiscing an African Connect: The Impregnable Janjira
}

\author{
Dr CS Anuradha*
}

\begin{abstract}
While India-African historical relations often relate only to Indians settling or making a mark in the African continent during the modern era or the linkages between strong African empires and Indian kings or trading interests, there are instances of Africans reaching India and later even becoming rulers. Unlike other slaves sent to several parts of the world, the African slaves brought to India worked up the social ladder and reached great heights. They were called the Siddis. Initially, the Siddis served in the army of the Ahmadnagar Nawab and later due to their war making prowess were granted posts of commander.
\end{abstract}

The Siddis built the sea-fort of Janjira. The name is derived from the Arab word "Jazeera" meaning island. It is an island fort and the distinction of the fort is that it has never been captured by any ruler including the formidable Maratha ruler, Chatrapathi Shivaji. Despite Shivaji himself having built numerous forts dotting the Maratha landscape, he was unable to capture the Siddis-built Jal Durg even after 13 attempts. The approach to the fort is almost invisible till one is very near the fort. The fort housed palaces and tombs for the early Siddi commanders and rulers. The fort continued to be free till the years of the British Raj when it came under their control.

This article seeks to bring out the historical and strategic significance of the fort that exhibits the skills of the African rulers in India and its enduring charm today.

KEYWORDS: Siddis, Maritime History, India, Janjira Fort, Indo-African Relations, Malik Ambar, Maratha History, Bijapur Sultan 


\section{Reminiscing an African Connect: The Impregnable Janjira}

\section{Neglected aspect}

Whenever there is reference to India-Africa Relations, it is often indicative of civilisational ties between ancient Egyptian and Indian empires. The most famous record being the Asokan $13^{\text {th }}$ rock edict, mentioning the Indian King's contact with Ptolemy II, the ruler of Egypt. It is also said that Dionysius was Ptolemy's ambassador in Asoka's court (Subbanna, 2007). The Kingdom of Axum that existed in modern day Ethiopia had extensive trade ties with India. The ancient port of Adulis in the eastern part of the country is where the Indians traded silk and spices for gold and ivory (Embassy of India in Addis Ababa, 2018).

Also it refers to the commercial ties furthered by colonial commonality. The movement of Indian labour and businessmen during and just after the colonial period often remains the launch pad of any historical trace. At present, the deepening interest in the African continent as a whole for countries like China has evoked calls for renewal of ancient contact. However, the one aspect that is seldom referred to is the African rulers in India.

This is despite the fact that they have occupied Indian political realm from as early as the $12^{\text {th }}$ century and established their control over both eastern and western parts of India.

\section{Siddi story}

There are several unique features in Africans ruling parts of India. Principally, they were not invaders like Mughal or other dynasties that claimed control over large parts of India. They came to India as slaves. They were also not recruited as labourers but they were employed for military purposes only. This distinguished them from the slaves who were taken to the Western hemisphere where they served as bonded labourers under extremely inhumane conditions and were often discriminated against. This might also be one of the causes for their rise in the social ranks that could put them in close proximity with the then rulers.

The characteristics of loyalty, physical prowess and administrative acumen exhibited by the African slaves made them indispensible to the smaller kings who were faced with political and military challenges. 
Their military capabilities were time and again proven by the successful counter to enemy attacks that further added to their power and prestige in the kingdoms they had pledged loyalty to. With ingenious tactics the African slave soldiers could stave off a strong challenge from stronger and mightier armies like those of the Mughals. Thus they remained the biggest hurdle in the Mughal plans to usurp power and establish complete control over southern parts of India. The Siddis are also credited with developing guerrilla tactics called bara-giri to deeply affect enemy lines of supply (Rangarajan, 2008). This frustrated the imperial ambitions of many rulers.

The African slaves hailed mostly from Abyssinia now Ethiopia and were hence referred to as Habshis and respectfully as Siddis. They came to India as early as $7^{\text {th }}$ century and later in the $12^{\text {th }}$ and $13^{\text {th }}$ centuries. They were termed the guardians of the Indian Ocean region as the "Habshis" were the sailors who accompanied the Arab ships to ward off pirates. In an account, the famous traveller Ibn Batuta talks of how they were guarantors of safety on the Indian Ocean and if they are on a ship it will be avoided by Indian pirates and idolaters (Jayasuriya \& Pankhurst, 2003, p. 192).

It is even said that as early as the $12^{\text {th }}$ century, Razia Sultana, the first woman ruler of Delhi had an African confidant Jamal ud din Yakut. The Turkish and other nobles were upset and it is even said to be the cause of a rebellion against the empress.

In the East in Bengal, Barbak Shahzada founded the Habshi dynasty in 1487 and crowned himself Ghiyaz al din Firuz Shah. His successor Saifuddin Firuz Shah built the famous Firuz Minar at Gaur, Malda in Bihar. The Minar in Bihar is a testament to their architectural skills. It resembles the Qutb Minar and is a madhana or a single tower that serves both as a victory tower and proclamation of the Sultan's religious fervour (Gupta, 2006, p. 734). The rule of the dynasty was short-lived and ended in 1493. In the $15^{\text {th }}$ century, Siddi Masood the vizier of Bijapur, a Siddi merchant redesigned the Adoni fort and built the Shahi Jamia Masjid. Aurangazeb captured it in 1686 after a valiant fight by the Siddi. The Siddis also rebuilt the Adoni Fort.

Siddi Masud Khan served as chief minister of the Bijapur in the $16^{\text {th }}$ century. Siddi Ikhlas Khan was the vizier of Bijapur under the sultan Muhammad Adil Shah. Malik Sandal, a Siddi was a great architect who built Ibrahim Rauza the famous funerary complex for Ibrahim Adil 
Shah II of Bijapur in 1627. It could have been "a close challenger" to the Taj Mahal due to its grandeur and beauty (Chang, 2018). The innate ability to adapt to situations and extract maximum leverage and the benevolence shown as rulers were also significant factors that made reigns unchallenged. The Siddis were devout Muslims and has great interest in arts and architecture.

The African slaves bound for India also did not face any racial prejudice. They experienced social mobility and acceptance within the higher echelons of society. This enabled them to at times reach the top of the societal ladder. They rose in military ranks to first command small army units and later entire armies. Some became powers behind the throne and in a few cases when the Indian kings were either weak or unable to govern they assumed the role of the ruler.

\section{The Dark One}

Malik Ambar named Shambu or Chapu hailed from the highlands of Ethiopia. Due to poverty he was sold off as a slave landing first at the Red Sea port of Mocha from where he was purchased by another Arab and taken to Basra. He learnt Arabic and was taken to Ahmadnagar by his master erstwhile slave himself, Chengiz Khan.

Chengiz Khan was a freed slave and had considerable influence in the Deccan court. From him, Malik Ambar learnt the intricacies of Deccani politics. He moved up to be an able military general who was a nightmare to the mighty Mughals including Akbar and Jehangir (Bishop, 2013).

In fact the fantasised depiction in a painting of Emperor Jehangir standing atop the world aiming for the beheaded Malik Ambar with a bow and arrow is a clear indication of his role in preventing Mughal dynasty from over running the Deccan (Khilnani, 2016, pp. 178-187). Even at the age of 76, he could triumph over the combined forces of Mughal and Bijapur at the Battle of Bhatwadi in 1624 (Anwar, 2005). His trusted right hand man was Maloji the Maratha chief who was Shivaji's grandfather (Ramachandran, 2008).

He was a very able administrator and built a new city now called Aurangabad. The city comprised of streets, waterworks, palaces and protected it with a strong surrounding wall 
from Mughal ambitions. Though the city was fed by the river Kham he constructed an elaborate network of canals, conduits, aqueducts, and reservoirs. The network called Nehr-eAmbari operates to this day. The Panchakki is the famous watermill that has an underground water fountain some $8 \mathrm{kms}$ away as its source. He also built his own mausoleum near Kuldabad. It was of pink basalt and is an example of exquisite architectural traditions and stands to this day as a testament of Siddi artistic leanings.

\section{Janjira Jigsaw}

Of particular interest is the Janjira Fort attributed to the Siddi General Malik Ambar. The fort that was never captured is an embodiment of the undisputed power of African rulers in India. Malik Ambar hailed from the Abyssinian highlands.

Malik Ambar is also credited with strengthening the Sea Fort of Janjira the only fort that has never been captured. It is located on a small island in the Arabian Sea. There are several special features to the fort. Firstly the shape of the fort is not the common round but oblong. Secondly, the entrance to the fort is practically invisible unless you are very close to it. Also, in its heyday it is said that the fort was defended soundly by the stationing of a maximum of 572 canons including three of the largest ever found in India. The fort housed a series of palaces, fresh water tanks, mausoleums and other structures. The maintenance of fresh water tanks in the middle of the sea is remarkable.

The fort entrance has a stone carving depicting six elephants trapped by a single tiger symbolising the bravery of the Siddis. On the right side from the entrance is the Peer Panchayatan that houses the graves of five saints or peers. In the middle of the fort lies the Surulkhan palace that is said to have had five storeys. There was also the Jumma Masjid or mosque in the fort premises. North of the palace lies the lake which is $20 \mathrm{~m}$ wide. The lake was supposed to have a multicoloured dome as canopy that resembled that of a rainbow. It was fittingly called the Sheesh Mahal. The present ruins also boast of a granary room, armoury and a multi-storey Durbar hall. The presence of freshwater lakes in the midst of the saltwater in the sea which is available to this day is nothing short of an engineering feat.

Ahead from the lake lies the citadel behind which is the Royal Courtyard. The fort also houses an emergency exit at the Western end of the fort. This was an underwater tunnel that led all the way to the mainland to Murud-Janjira. 
The fort has a 40 metre wall the sheer made of black stone with 20 bastions which are rounded in shape. The fort walls were plastered with a mixture of lime, glass and jaggery that has withstood the ravages of time and the corrosive seawaters. The fort was guarded by more tha 500 cannons of which three are the biggest in the whole of India. The largest ones were named Kalal Bangadi, Landakasam and Chavari. They are a metallurgical marvel as they are made with a mixture of five metals that made the resultant alloy heat-resistant. The Kalal Bangadi has five rings that have been cast using the forged-welded method. It weighs 22 tonnes. The Chavari on the other hand weighed 3.32 tonnes. The Landa Kasam was 7.45 tonnes in weight (Deshpande, Joshi, \& Kadgaonkar, 2011).

The cannons could reach a distance of $12 \mathrm{kms}$ with their fire power (Rediscovery Project, 2018). A modern day attempt to map many of these cannons has been attempted (Singh, 2015). The cannons were strategically placed to ward off any attack on the fort.

The Janjira fort is straddling the coast and serves as a vital lookout post for any possible ingress into the Konkan coast. The height of the fort walls at 40 feet were virtually incapable of being surmounted. This was further strengthened by the inaccessible fort gates that were almost invisible from a long distance. This made the enemy vulnerable to attacks from the 500 odd cannons placed strategically all around the fort. The approach of the enemy to the gates was enough warning to set off defensive attacks that completely decapitated the invaders.

The fort defeated numerous attempts numbering thirteen to capture it by the Maratha ruler Chatrapathi Shivaji. He built a plethora of forts that dot Western India. After conquering the Khalegad, Ghasalgad and Raigad forts, the Maratha ruler set his sights on Janjira realising its strategic importance. In 1659, his initial attempt by despatching his lieutenants Shamraj Pant and Bhaji Golap proved futile. Next Nilopant Raghunath Mujumdar and Mayaaji Bhatkar though surrounded the fort were unable to capture it. Shivaji even sent an army with Vyankoji Datto to counter the Siddis who rebutted the challenge. In 1670 the Maratha chief's attack on Janjira was defeated with help from the Mughals and the Maratha sailors suffered heavy casualties. The repeated attempts till 1678 proved unsuccessful.

Shivaji's son Sambhaji was also not successful in trying to capture Janjira. It is said that instead of attacking the mouth of the fort, the Maratha scion employed an ingenious idea of 
digging his way into the fort. The vain effort resulted in the accumulation of so much soil it is said that it resulted in the construction of the Padma Durg opposite to the site of the Janjira on Maratha mainland.

Apart from Indian kings, the British, Portuguese and Dutch too were unable to capture the fort. The impregnable fort passed on to the British upon independence but remained undefeated till then. For most of the $17^{\text {th }}$ century the Siddis were at war with the Marathas, the Mughals and the British. Siddi Yakut Khan put up a brave front against the British and confiscated British armoury and money. The British ended hostilities only after a treaty of friendship in1733 (Bhatt, 2018).

The Portugese who had established supremacy in the on shore areas also attempted several times to subjugate the Siddi stronghold. As early as 1589 Janjira together with the Ottomans, thwarted a Portugese fleet off the Yemen coast (Venkatesh, 2017). The Siddis adopted the fast attack tactic and prevented Portugese ships from reaching Janjira. The Dutch were also rebuffed by the diligent Siddis. Even the superior British firepower and strategies did not produce results and the Siddis remained virtually undefeated till independence.

\section{Conclusion}

The Siddis as a tribe continue to live in India and Pakistan, though in dwindled numbers. They have been marginalised in Indian society and received their tribal status in 1984. They are mainly found in Gujarat, Karnataka and parts of Hyderabad. During the late part of $19^{\text {th }}$ century African Cavalry Guards were gifted to the Nizam. Their descendants still live in the AC Guards Colony of the city. Nearly 250,000 of African descent live on the Makran coast of Pakistan. Recently in the Pakistan general elections, a Siddi woman, Tanzeela Qambrani was elected to the South Sindh legislature on a Pakistan People's Party ticket (Sihail, 2018).

The pages of Indian maritime military history will certainly cherish the African connect at Janjira for eternity. Chronicling the military strategic significance of such forts and other structures would greatly contribute to the rich heritage of India's maritime legacy. The unique architectural details that added to the strength of these defensive structures can certainly inform future maritime technologies. Examination of the armament composition that aided in making the fort undefeatable is also warranted. An in-depth study into the tactical aspects of 
some of the abovementioned attempts to capture the Janjira Fort is thus pertinent. A comparative approach to analyse the different modes adopted by Maratha rulers to defend their coastal forts or use them as launch pads for landward plans vis a vis those made to overpower Janjira would augment knowledge on Maratha military prowess. The success of the Siddi tactics in marine fort defence could help in evaluating the maritime might of various challengers including western sea powers and assess the chinks in their sea-based armour. With artificial islands being constructed as part of modern maritime defences, the strongest marine fort in India could offer practical pointers in making such structures impregnable. Perhaps the fort itself could be reinvented to serve as a modern outpost to man the Arabian Sea expanses, given the area's importance in India's modern maritime calculus.

\section{References}

Anwar, S. (2005). Impact of Prince Khurram's revolt on the Mughal campaigns (1617-26). Studies in Humanities and Social Sciences, 12(2), 39-50.

Bhatt, P. M. (2018). The African Diaspora in India. London: Routledge India. doi:https://doi.org/10.4324/9781315148380

Bishop, M. (2013, May 03). PHOTO ESSAY: Africans in India. Retrieved from https://afropop.org/: https://afropop.org/articles/photo-essay-africans-in-india

Chang, A. (2018, February 14). Beauty and Majesty of the Adil Shahi Architecture of the Jumma Masjid in Bijapur. Retrieved from https://www.talkativeman.com/: https://www.talkativeman.com/author/Aileen_Chang/page/2/

Deshpande, P., Joshi, S., \& Kadgaonkar, S. (2011). Catalogue Of Forge Welded Iron Cannons. Indian Journal of History of Science, 46(4), 683-693. Retrieved from https://www.insa.nic.in/writereaddata/UpLoadedFiles/IJHS/Vol46_4_8_PPDeshpande.pdf

Embassy of India in Addis Ababa. (2018, November 04). Commercial Bilateral Relations. Retrieved from The Embassy of India in Addis Ababa, Ethiopia: http://indembassyeth.in/commercial-bilateral-relations/

Gupta, O. (2006). Encyclopedia of India, Pakistan and Bangladesh. New Delhi: Gyan Publishing.

Jayasuriya, S. d., \& Pankhurst, R. (2003). The African diaspora in the Indian Ocean. Trenton, NJ : Africa World Press. Trenton, NJ: Africa World Press.

Khilnani, S. (2016). Incarnations: A history of India in 50 lives. New Delhi: Penguin India. 
Ramachandran, N. (2008, October 12). Malik Ambar: Military guru of the Marathas. The Hindu. Retrieved from http://www.thehindu.com/todays-paper/tp-features/tpsundaymagazine/Malik-Ambar-Military-guru-of-the-Marathas/article15402097.ece

Rangarajan, A. (2008, October 12). Malik Ambar: Military guru of the Marathas. The Hindu. Retrieved May 02, 2020, from A.Rangarajan, Malik Ambar: Military guru of the Marathas, The Hindu, October 12, 2008 http://www.thehindu.com/todays-paper/tp-features/tpsundaymagazine/Malik-Ambar-Military-guru-of-the-Marathas/article15402097.ece: http://www.thehindu.com/todays-paper/tp-features/tp-sundaymagazine/Malik-AmbarMilitary-guru-of-the-Marathas/article15402097.ece

Rediscovery Project. (2018, April 23). Murud Janjira's African past and the mystery of the Boab tree. Retrieved from https://rediscoveryproject.com/: https://rediscoveryproject.com/2018/04/23/murud-siddis-janjira-fort/

Sihail, R. (2018, August 08). Pakistan's first lawmaker of African descent raises hopes for Sidi community. Retrieved from www.bbc.com: https://www.bbc.com/news/world-asia45099970

Singh, D. (2015, December 21). Recreating lost history: Archaeologist maps 235 cannons of Chhatrapati Shivaji's era. Retrieved from https://indianexpress.com/: https://indianexpress.com/article/cities/mumbai/recreating-lost-history-archaeologist-maps235-cannons-of-chhatrapati-shivajis-era/

Subbanna, S. R. (2007, March 30). Cultural Relations between Ancient India and Egypt. Retrieved from All Empires Online History Community: http://www.allempires.com/article/index.php?q=egypt_india_ancient_relations

Venkatesh, K. (2017, April 16). India's African heritage. Retrieved from www.livemint.com: https://www.livemint.com/Sundayapp/p7LfTiQKXkTXkZHNBSZbLO/Indias-Africanheritage.html 